\author{
Michał Chaberek \\ Cardinal Stefan Wyszyński University in Warsaw \\ ORCID: 0000-0001-8071-537X
}

\title{
The Teaching of the Church on Religious Freedom: A Break or Continuity of Tradition?'
}

\begin{abstract}
This paper elaborates upon the Catholic Church's teaching on religious freedom in the period from The French Revolution to The Second Vatican Council. Based on quotations from the original documents, the author presents the evolution of the Church's position that switched from the initial rejection to the final acceptance of the religious freedom over past two centuries. The fact of this dramatic change begs the question about the continuity of tradition and credibility of the contemporary position of the Church. Based on the document by the International Theological Commission, "Memory and Reconciliation: The Church and the Faults of the Past," as well as the teaching of Pope Benedict XVI, the author demonstrates that - in contrast to some contemporary interpretations - the hermeneutics of continuity is possible regarding Church's teaching on religious freedom.
\end{abstract}

Keywords: Freedom, Church, State, The Second Vatican Council, Pius XII, Leo XIII, religion, conscience

The problem I would like to elaborate on in this article was most precisely formulated by the German philosopher and lawyer Prof. Ernst Böckenförde. In his book Freedom - State - Church he included the words:

${ }^{1}$ This article is a translation of the article originally published in Polish: Michał Chaberek, "Nauczanie Kościoła o wolności religijnej - zerwanie czy ciągłość tradycji?," Collectanea Theologica 86 (2016) no. 1, 107-136. Translated from Polish by Maciej Górnicki. 
"Reducing the pre-conciliar teaching [on religious tolerance] - regardless of its nuances on particular issues to its core content, it must be said that it meant a distortion of natural law, which the Church has strongly supported and still supports in other areas." And in another place: "The Declaration [Dignitatis humanae], while recognizing individual religious freedom and, consequently, the freedom of public worship, contradicts the content of Syllabus of Pius IX of 1864, his encyclical Quanta cura of 1864 and Pope Leo XIII's encyclical Libertas of 1888. The relation of the content of the Declaration to these statements of the Pontifical Teaching Office is as 'A to non-A.' Therefore, it is not acceptable to use here the usual interpretation that the Council has only further developed the previous teaching of the Church. The teaching contained in these documents was simply abolished by the Declaration."

Böckenförde, analyzing the teaching of the Magisterium on freedom over the last two centuries, concluded that there is no continuity, but a break with a certain paradigm that took place during the Second Vatican Council through the declaration Dignitatis humanae. My goal is to try to answer the question whether the socalled "hermeneutics of continuity" is possible with regard to the Church's teaching on religious freedom, or rather, as Böckenförde sees it, is there a break with tradition?

\section{The Development of the Church's Teaching}

\subsection{The period of unequivocal condemnations}

The misfortune in the history of Church teaching about freedom was that the idea of freedom was born in opposition to the traditional Christian social order that the Enlightenment inherited from previous eras, especially the Middle Ages. During the Enlightenment, the concept of freedom began to be used instrumentally, as a slogan that, in extreme cases, justified the most radical actions against public order, including bloody actions against

${ }^{2}$ E.-W. Böckenförde, Wolność - Państwo - Kościót, transl. P. Kaczorowski, Kraków: Znak, 1994, 58, 70. 
the clergy and Church property. The first statement of the Magisterium, touching upon the question, appeared in the context of the struggles and disputes of the Great Revolution in France. Pope Pius VI in March 1791 announced the breve Quot Aliquantum condemning the Civil Constitution of the Clergy and the revolutionary principles of liberty and equality. ${ }^{3}$ Among the reflections on the practical policies and the current situation of the French Church, the breve included such sentences:

\begin{abstract}
"It is by its (National Assembly) resolution that it is announced that it is laid down in law that a man living in society should enjoy all kinds of freedom, which also means that he must not be disturbed [turbari] with regard to religion, and it is up to him to judge whatever he wishes about his own religion, to speak, to write, and even to distribute it in print."
\end{abstract}

In these words, Pius VI expresses his regret about the principle adopted by the authority in power in France (National Assembly) that everyone can have any religious beliefs, and that, moreover, he or she can not only nourish these beliefs inside himself or herself, but also distribute them in print. This, of course, is a statement set in the context of the events in revolutionary France. However, the successors of Pius VI were mostly inclined to uphold his position.

\footnotetext{
${ }^{3}$ A contemporary author commenting on this statement writes: "It is difficult to imagine today [...] that an ex cathedra statement condemning the theses of the Declaration [of 1789] was uttered and set in opposition to divine law. This is mainly the Encyclical Adeo nota and the Apostolic Letter Quod aliquantum of Pius VI of 1791, condemning the French Declaration of Human and Civil Rights of 1789. The same line with the normative acts of intra-state protection of human rights was maintained by the successors of Pius VI: Pius VII in his apostolic letter Post tam diuturnam (1814), Gregory XVI in his encyclical Mirari vos (1832) and Pius IX in his encyclicals Nostis et nobiscum (1849) and Quanta cura (1864)." K.F. Papciak, "Stolica Apostolska a ONZ wobec praw człowieka w relacjach międzynarodowych," in Saeculum Christianum, 6 (1999), No 1, 189-99.

${ }^{4}$ Self-translation based on text in: Collectio Bullarum, Brevium, Allocutionum, Epistolarumque PP. Pii VI contra constitutionem civilem cleri Gallicani ejusque authores et fautores, etc. Londini: Ex officina Cox et Baylis, Great Queen Street, Lincoln's-Inn-Fields, 1821, 24-5.
} 
The first "developed" teaching rejecting freedom of religion and conscience is found in Pius IX, who in his encyclical Quanta cura (1864) opposed the views of naturalists about the state. For the naturalists taught:

„[T] hat the best form of Society, and the exigencies of civil progress, absolutely require human society to be constituted and governed without any regard whatsoever to Religion, as if this [Religion] did not even exist, or at least without making any distinction between true and false religions." Contrary to the teachings of the Holy Scriptures, of the Church, and of the Holy Fathers, these persons do not hesitate to assert, that the best condition of human society is that wherein no duty is recognized by the Government of correcting, by enacted penalties, the violators of the Catholic Religion, except when the maintenance of the public peace requires it." 5

Out of this they derive the most disastrous teaching, which was condemned already by Gregory XVI:

"[T]hat the liberty of conscience and of worship is the peculiar (or inalienable) right of every man, which should be proclaimed by law, and that citizens have the right to all kinds of liberty, to be restrained by no law, whether ecclesiastical or civil, by which they may be enabled to manifest openly and publicly their ideas, by word of mouth, through the press, or by any other means"

In the first of these statements, Pius IX opposed treating as equal the true and false religion in society. In addition, he opposed the view of naturalists, who rejected the state's obligation to stop opponents of the Catholic religion with legal penalties. In the second one, the Pope spoke out against absolute freedom in the matter of religion and against similar freedom to express one's views in the

\footnotetext{
${ }^{5}$ Pius IX, Quanta Cura, in Encyclical Letter Quanta Cura \& the Syllabus of Errors: of the Supreme Pontiff Pius IX: Condemning Current Errors: December 8, 1846. Kansas City (MO) 1998, 5.

${ }^{6}$ Ibid.
} 
means of communication. It is worth noting here that the Pope rejects an extreme position on the question of religious freedom, arguing not against freedom in general, but against its absolute form. In practice, it is not known how much freedom would be granted to the infidels, but the fact is that Pius IX maintained the state's obligation to punish the enemies of Catholicism, even if their activities did not threaten public peace.

Following the text of the encyclical were the rejected statements included in the Syllabus attached to it. Three statements numbered 77 to 79 included religious freedom. They are worth quoting here in their entirety:

„77. In the present day it is no longer expedient that the Catholic religion should be held as the only religion of the State, to the exclusion of all other forms of worship.

78. Hence it has been wisely decided by law, in some Catholic countries, that persons coming to reside therein shall enjoy the public exercise of their own peculiar worship. 79. Moreover, it is false that the civil liberty of every form of worship, and the full power, given to all, of evenly and publicly manifesting any opinions whatsoever and thoughts, conduce more easily to corrupt the morals and minds of the people, and to propagate the pest of indifferentism."

The method of content presentation in the Syllabus does not facilitate interpreting its right message. ${ }^{8}$ Now let us try to recreate the positive thought contained in Pius IX's teaching. First of all, it is impossible to arrange social life so that it has no reference to religion. However, this is still not enough, since the Catholic religion should be distinguished by public authority. Moreover, in the practice of state life, the public authority should stop the propaganda of opponents of the Catholic religion by punishments. Catholicism, as the true religion, should be recognized as the state religion.

\footnotetext{
${ }^{7}$ Pius IX, Syllabus errorum, in Encyclical Letter Quanta Cura \& the Syllabus of Errors: of the Supreme Pontiff Pius IX: Condemning Current Errors: December 8, 1846. Kansas City (MO) 1998, 23.

${ }^{8}$ On this topic see an ample article by F.R. Hittinger, "Pascendi Dominici Grgis at 100," in Nova et Vetera English Edition, vol. 4 (2006) No. 4, 853.
} 
Restrictions on external worship should be imposed on followers of other religions, as public proclamation of these worships promotes indifferentism. Further, the freedom to preach freely leads to the corruption of characters and morals. It is worth observing two points in this context: First of all, religious freedom is once again linked to the possibility of committing an error, to the extent that such freedom must inevitably lead to distortions of morality. Secondly, the limitations of which Pius IX speaks only concern the external sphere. However, the Pope does not speak on the question of freedom to choose one's religion in conscience. This freedom is guaranteed by the fact that religion can never be accepted by compulsion. Man remains free inwardly.

\subsection{The period of first distinctions}

The pontificate of Leo XIII contributed greatly to the development of the concept of religious freedom. In the encyclical Immortale Dei (On the Christian State) of November 1, 1885, the Pope presented his teaching on state order, authority and system. The encyclical also contains some remarks on the relationship between the state and religion. In the teaching of Leo XIII, worship is due to God by virtue of natural law, which means that it is as common as reason proper for human beings. A community, like every individual, owes worship to God, and not any kind of it, but such as God Himself has commanded with numerous signs:

"Now, it cannot be difficult to find out which is the true
religion, if only it be sought with an earnest and unbiased
mind; for proofs are abundant and striking. We have, for
example, the fulfilment of prophecies, miracles in great
numbers, the rapid spread of the faith in the midst of enemies
and in face of overwhelming obstacles, the witness of the
martyrs, and the like. From all these it is evident that the only
true religion is the one established by Jesus Christ Himself,
and which He committed to His Church to protect and to
propagate."

${ }^{9}$ Leon XIII, Immortale Dei, No. 7, http://www.vatican.va/content/leo-xiii/en/ency clicals/documents/hf_l-xiii_enc_01111885_immortale-dei.html. 
It should be noted that the Pope, maintaining that the state should support a particular religion, indirectly postulates a true religion being recognized by the state authorities. If the authority is independent in its actions, which is also mentioned in the document, then the choice of cult also belongs to it.

In the later part of the document there is a description how the medieval European civilization came about, which Leo XIII speaks of (not without nostalgia) as an order in which the Church's requirements found their harmonious solution in the political order. Later, however, (since the $16^{\text {th }}$ century), this "pernicious thirst for novelty" appeared, first destroying the order in Christianity itself, and then moving on to philosophy and from there on to a new social system, which contradicted not only Divine but also natural law. This system takes as its basic premise:

"[T]hat as all men are alike by race and nature, so in like manner all are equal in the control of their life; that each one is so far his own master as to be in no sense under the rule of any other individual; that each is free to think on every subject just as he may choose, and to do whatever he may like to do; that no man has any right to rule over other men." 10

The result of this understanding of authority is that the crowd rules as "master and lord" for itself and the state no longer feels any duty to God and does not profess any religion in public. As a result, all religions are equal, with the sole proviso that they do not harm the state order. Finally:

"[...] all questions that concern religion are to be referred to private judgment; that every one is to be free to follow whatever religion he prefers, or none at all if he disapprove of all. From this the following consequences logically flow: that the judgment of each one's conscience is independent of all law; that the most unrestrained opinions may be openly expressed as to the practice or omission of divine worship;

${ }^{10}$ Ibid., No. 24. 
and that every one has unbounded license to think whatever he chooses and to publish abroad whatever he thinks." 11

Total arbitrariness in the matter of professed religion leads to subsequent deplorable results. The Church voice is no longer respected by people, and even her natural laws are being violated. Divorce is allowed, property of the Church and priests is confiscated, young people are deprived of their religious education, the Church State is subject to seizure. It is therefore clear that "reason itself condemns such state theories."

Later on, however, Leo XIII seems to have softened his position to some extent. Writing about the Church's desire for harmony between the two authorities, that is, that of the Church and state, the Pope allows for a pluralism of forms of government, as well as true and just freedom and, in a sense, religious pluralism. I will refer here to a very important part of the Encyclical:

„The Church, indeed, deems it unlawful to place the various forms of divine worship on the same footing as the true religion, but does not, on that account, condemn those rulers who, for the sake of securing some great good or of hindering some great evil, allow patiently custom or usage to be a kind of sanction for each kind of religion having its place in the State. And, in fact, the Church is wont to take earnest heed that no one shall be forced to embrace the Catholic faith against his will, for, as St. Augustine wisely reminds us, "Man cannot believe otherwise than of his own will."'12

In this statement, Leo XIII allows for religious tolerance in practice in the case when combating other faiths could lead to greater evil or prevent the realization of some greater good. Leo XIII goes on to explain this evolution of teaching by clearly distinguishing freedom as arbitrariness from freedom ,truly genuine, and to be sought after, which in regard to the individual does not allow men to be the slaves of error and of passion, the worst of all masters; which, too, in public administration guides the citizens in wisdom

\footnotetext{
${ }^{11}$ Ibid., No. 26.

12 Ibid., No. 36.
} 
and provides for them increased means of well-being; and which, further, protects the State from foreign interference." 13 Such freedom has always been praised and defended by the Church. It contributes to the prosperity of societies, serves to end the princes' arbitrariness towards the people and protects the state from foreign violence.

This, perhaps slightly incoherent, teaching on religious freedom was clarified by Leo XIII three years later in another document the encyclical Libertas. The encyclical was a broad lecture of papal views on freedom. It also devotes a lot of space to discuss religious freedom. The starting point for this is the Pope's renewed statement that religious freedom is now a postulate of liberalism, which states that "everyone is free to either profess the religion he or she likes or not to profess any." Yet every man owes to God the virtue of religion, as he is subject to God, and without that virtue no other one will develop in man. ${ }^{14}$ Man, therefore, is obliged to profess a religion, which is once again taught by the infallible signs left by God himself. And further on it reads:

„Wherefore, when a liberty such as We have described is offered to man, the power is given him to pervert or abandon with impunity the most sacred of duties, and to exchange the unchangeable good for evil; which, as We have said, is no liberty, but its degradation, and the abject submission of the soul to sin." 15

If we now refer this doctrine to the whole state, it follows that the state cannot exempt itself from the duty of worshiping God, nor can it consider all religions as equal, because that would come down to atheism. And that is why the State is in favour of one religion, the one that is, of course, "the only true one, and which can be known without difficulty, especially in Catholic states." And supporting religion is beneficial to the state, both to those in power, since religion itself shows the Divine source of power, and to those who

\footnotetext{
13 Ibid., No. 37.

${ }^{14}$ Leo XIII, Libertas, No. 20, http://www.vatican.va/content/leo-xiii/en/encyclicals /documents/hf_l-xiii_enc_20061888_libertas.html.

15 Ibid., No. 20.
} 
are governed, since it contributes to good manners, and these in turn to freedom.

In response to the call of the proponents of liberalism concerning freedom of conscience, Leo XIII responds by making a clear distinction between two ways of understanding freedom of conscience. If one understands it in such a way "that everyone according to his own opinion is free to worship God or not to worship Him," it must be rejected. However, it can also be understood in the way: "that every man in the State may follow the will of God and, from a consciousness of duty and free from every obstacle, obey His commands. This, indeed, is true liberty, a liberty worthy of the sons of God, which nobly maintains the dignity of man and is stronger than all violence or wrong." 16

The proponents of liberalism reject this proper freedom. Here, however, comes the decisive turning point in the teaching of Leo XIII. Since the "current of minds" has already taken our century quite far and new freedoms have taken root in societies, the Church allows the public authorities to endure (tolerate) something contrary to truth and justice, in order to avoid even greater evil that could result from a struggle, or to save some good:
„But if, in such circumstances, for the sake of the common good (and this is the only legitimate reason), human law may or even should tolerate evil, it may not and should not approve or desire evil for its own sake; for evil of itself, being a privation of good, is opposed to the common welfare which every legislator is bound to desire and defend to the best of his ability." 17

After this lecture comes also a clarification that tolerance has its limits and is the result of "political prudence"; it is allowed due to the circumstances, but cannot be desired on its own.

Leo XIII's position definitely brings closer the issue of freedom, since it ultimately allows freedom of conscience and freedom of other religions under certain conditions. For the first time in the Church teaching, there is a clear distinction between two types of

\footnotetext{
16 Ibid., No. 30.

17 Ibid., No. 33.
} 
freedom - one that is moral licence and another which is the possibility to give the proper direction to one's life. If, however, as Leo XIII writes, "any liberty, except that which consists in submission to God and in subjection to His will, is unintelligible," 18 and this will can be clearly recognized in the only true religion, which is also recognized in a certain way by the "signs," then ultimately freedom comes down to the exercise of the rights of the Church. The overly strict deduction of practical indications taken from the general truths of the faith limits, in this vision, the concept of freedom to a "free matter" of which the Pope wrote. However, what issues fall within this matter is again determined by the Church. It can be said, therefore, that in the teaching of Leo XIII, the Church has moved from unequivocal condemnations of religious freedom to conditional tolerance. Tolerance, however, does not yet mean freedom.

Another document of importance from our point of view was the encyclical Mit brenneder Sorge of Pius XI of March 14, 1937. On the eve of the outbreak of war, the Pope intervened in this document in the case of the Nazi regime violating the provisions of 1933 concordat. The main subject of the document were issues related to the functioning of religious schools in the conditions of increasing repressions against the clergy and the entire Catholic community. In addition to explaining several theological issues, such as the understanding of original sin, the meaning of the Old Testament and the way God revealed Himself to the world, the Pope rejected the idea of a national church. However, among reflections on the law of nature, that is, the laws that belong to man by nature, Pius XI pronounced words that resembled those of the Second Vatican Council in their character:

"[M]an as a person possesses rights he holds from God, and which any collectivity must protect against denial, suppression or neglect" and further: "The believer has an absolute right to profess his Faith and live according to its

${ }^{18}$ Ibid., No. 36. 
dictates. Laws which impede this profession and practice of Faith are against natural law."19

The text of Pius XI clearly entails that man has an innate (natural) right, that is, a right which cannot be changed by any civil authority, to profess his faith. The position of Pius XII was formulated in the context of the persecution of the Catholic Church. Therefore, it is not known whether Pius XII favours the old teaching of "difficult tolerance" in societies where the Church has more influence. However, if the text is taken directly, it implies the personal freedom to profess one's faith, not only in the internal order, but also in public.

The last significant document on this issue before the Council was the speech of Pius XII Ci riesce at the Congress of Catholic Lawyers in Italy on December 6, 1953. In his speech, Pius XII starts from the observation of the internationalization of social life, which takes place under the influence of the phenomenon, good in the eyes of the Pope, of ever closer contacts between people. Therefore, a phenomenon of an "international community" appears. One of the problems of this new situation is the coexistence of Catholic and non-Catholic states in a single, seemingly superior structure. The juridical principle governing such a structure would be formulated in such a way that:

"[W]ithin its territory and with regard to its own citizens, each state will regulate religious and moral matters according to its own laws. However, with regard to the territory of the entire international community, the citizens of each member state will be allowed to express their convictions and carry out their own ethical and religious practices, as long as they do not violate the criminal law of the state in which they reside." 20

In this context, the question should be asked whether Catholics can agree to this legal principle? Before Pius XII gives

${ }^{19}$ Pius XI, Mit brennender Sorge, No. 30-1, http://www.vatican.va/content/piusxi/en/encyclicals/documents/hf_p-xi_enc_14031937_mit-brennender-sorge.html.

${ }^{20}$ Pius XII, Ci riesce, Warszawa: Te Deum, 2004, p. 9-10. 
a positive answer, he makes an important distinction. Namely, according to the Pope, we face two issues here. The first one concerns the objective truth and the duty of conscience towards what is objectively true and good. The second is related to the practical attitude of the international community towards a sovereign state, as well as the attitude of that state towards the international community, including that which relates to religion and morals. As for the former, it is clear that "no human authority [...] can issue a positive order $[. .$.$] to teach or do what is contrary to religious truth or moral$ good." In response to the second question, Pius XII starts from the question whether it would not be possible for God to "easily" eliminate religious and moral errors? But since God does not do this himself, man too must follow the parable of the wheat and the tares, where good and evil exist together until the end of the world:

"God does not approve of them [error and sin], but lets them exist. Therefore, the claim that religious and moral error should be suppressed whenever possible, because tolerating it would be immoral in itself, is not entirely and unconditionally correct." 21 And further on: "The obligation to suppress moral and religious error cannot, therefore, be the ultimate criterion of conduct, but must be subordinated to higher and more general norms which, under certain circumstances, allow for the toleration of error, and even seem to indicate tolerance as a better way of obtaining the greater good." 22

In these words Pius XII as the first of the popes rejected expressis verbis the principle of combating religious error. Thus, in Pius XII, the argumentation is as follows: an error is not acceptable, what is religiously wrong and morally evil must be rejected. In this regard, the teaching of the Church is unchangeable de iure and de facto. However, for the sake of the common good (bonum commune), which is a higher reason, the Church has always been inclined to act and has acted with tolerance. Both the good of the Church (particular and universal) and the good of the state depends on this.

${ }^{21}$ Ibid., p. 11.
${ }^{22}$ Ibid., p. 12. 
Pius XII did not therefore withdraw the principle of tolerance as a way of reconciling the existence of different religions in one country or international community. However, an important novelty of his doctrine was the introduction of a hierarchy of orders. While Leo XIII reminded the distinction between secular and spiritual power, so important for Christianity, Pius XII complemented this teaching by recalling the existence of temporal and eschatological order. The solution of Pius XII was based on the distinction between absolute truths, from which concrete solutions of the statute law arise only by means of adaptation. There is no simple deduction between them, sometimes the specific laws revealed by God in Scripture and in the tradition of the Church must find expression in state law in the form of more general norms. According to B. Sesboüe Pius XII, compared to Leo XIII, introduces two innovations, namely, he rejects the denominational state and the principle of combating religious error. ${ }^{23}$

The next step in this matter will be taken by John XXIII already during the Council, when in the encyclical Pacem in Terris (April $11,1963)$ he will put the issue of religious freedom as a problem that should be reflected in the statute law. ${ }^{24}$

\subsection{The state of the Church's teaching on religious freedom on the eve of the Second Vatican Council}

At the end of our discussion of the development of the Church's doctrine, we should reach for a synthesis by John Courtney Murray. This American Jesuit, one of the editors of the Council's document Dignitatis humanae, presented the Catholic Church position on religious freedom, as it was formulated just before the Second Vatican Council. According to Murray, although the doctrine of

\footnotetext{
${ }^{23}$ See: B. Sesboüe, Władza w Kościele. Autorytet, prawda i wolność, transl. P. Rak, Kraków: Wyd. M, 2003, 142.

24 "Also among man's rights is that of being able to worship God in accordance with the right dictates of his own conscience, and to profess his religion both in private and in public." John XXIII, Pacem in terris, No. 14, in Dokumenty nauki społecznej Kościoła, Pt. 1, ed. M. Radwan, Rzym-Lublin, 1996, 361-401. English text: http://www.vatican.va/content/john-xxiii/en/encyclicals/documents/hf_j-xxiii _enc_11041963_pacem.html.
} 
religious freedom had been gradually evolving, before the Council itself the Church had a coherent, developed and unequivocal teaching on religious freedom. In his book The Religious Freedom, ${ }^{25}$ Murray juxtaposed two points of view, which he described with neutral names - "First view" and "Second view." The first presented the teaching of the Church in a synthetic way, the second was Murray's own proposal. Before going on to discuss the Council's declaration, I will present here the "First view" which is a summary of all that the Church taught before the Council.

Murray starts by saying that in "The First" ("classical") approach, the problem of religious freedom is abstract and simple. It consists of two interdependent questions: moral, about the rights of conscience, and the "constitutional" question - about the legal order. Within the first question, different states of conscience are distinguished. The right conscience (conscientia recta) is a conscience formed subjectively in the light of higher norms, but also by norms that are objectively true (conscientia vera), and it is a Catholic conscience with full religious freedom, since this freedom is rooted in objective truth. This is a positive concept. In this sense, religious freedom is a requirement of human dignity. The Church has always defended such religious freedom in the face of persecution of the truth. But there can be a state of conscience (conscientia exlex), one that recognizes no higher standards than its subjective imperatives, possesses neither righteousness nor truth and cannot claim religious freedom because this freedom is rooted in religious truth. A right conscience, but not a true conscience (conscientia recta sed non vera), is a case of an erroneous conscience, which is nevertheless sincere. Such a conscience listens to higher norms, which, however, are not objectively true. This conscience guarantees internal, but not external, religious freedom. The internal personal religious freedom extends to the whole family, for example, the possibility of bringing up children in their faith. Some recognize the possibility of public worship here as well, while others exclude it, claiming that a public act of worship means spreading the cult, and that public authorities can never positively

25 J.C. Murray, The Problem of Religious Freedom, London-Dublin: Geoffrey Chapman, 1965. 
authorize the public existence of religious error. Only tolerance can be a legal reference to an error. On the other hand, the authorities have no right to interfere with the internal freedom of personal conscience or the freedom of the family by imposing a religion or practice of any religion or ideology.

The "constitutional" issue in this approach is resolved by distinguishing between theses and hypotheses. The thesis states an ideal - a concern for religion, which the law must ensure in itself and in principle. The hypothesis defines the concessions that must be made in specific circumstances. The thesis assumes two general statements. The first is that the state is founded not only on natural law, but also on positive Divine law, by which the Church has also been established. Therefore, the state has the duty to recognize in the statute law that the Church is the perfect community sui iuris, and that it is the only religious community that has the right (iure divino) to exist and act in public. Since, under God's law, Catholicism is the only true religion, it must be, under established law, the only state religion. It follows that no other religion can have by itself and in essence a statutory right to public existence and action in society. A religion that does not have the right to exist iure divino, can also not have the right to exist iure humano. Therefore, all false religions, on their own and in principle, should be put outside the margin of public life and social activities. Hence, the thesis accepts legal intolerance as a logical and practical consequence of the order of the established law (unica status religio). Together, these two tools (intolerance and the relevant legal order) show the ideal solution to the "constitutional" issue. The solution is internally consistent: the superior legal principle - the exclusive rights of truth - is transformed into the statutory acceptance of a single state religion. There are two reasons for intolerance: first, that a religious error can be justifiably repressed because, since "error has no rights," no harm is done by repression. It would be incomprehensible to oppose against repressions directed against what has no right to exist. Second, error should be repressed by the state. ${ }^{26}$

${ }^{26}$ Murray mentions four reasons in the teachings of the theologians of the time for which error and evil should be repressed: 1) error and evil are themselves contrary 
All of this constitutes the thesis, that is, it defines the ideal state of the "constitutional" question. It is the quaestio iuris. What remains is the quaestio facti, that is, the question of how to apply the ideal in practice. This question is answered by the hypothesis. The dichotomy of the thesis and hypothesis corresponds to the religious diversity of the people of the countries. In Catholic societies, the thesis is applied by itself and in principle (per se and in principle). In non-Catholic societies, the hypothesis is applied accidentally (per accidens), in a factual manner. The Church then renounces her right to establish one religion in the law with the legal consequence of legitimate intolerance, but at the same time does not give positive consent to such a legal situation. In itself, such a situation is bad, but it can be seen as a lesser evil than the damage that could result from the application of the thesis. Therefore, such a situation can be tolerated per accidens in practice. The superior principle that "only the truth has the right to exist" prescribes intolerance when possible and allows tolerance when necessary. The political criterion of whether tolerance or intolerance is applied is public peace. In a situation of Catholic unity, when other religions are in a clear minority, legal intolerance becomes possible without disturbing public peace and is actually a means to it. Legal tolerance, on the other hand, becomes necessary in conditions of religious pluralism when Catholics are in a minority. And this is also a means to public peace. The religious criterion here is the good of the Church, which in conditions of national Catholic unity is ensured by intolerance and elsewhere by tolerance.

Summarizing this point of view, Murray states that his basic premise is the exclusive right of truth ("falsehood has no rights") and the whole system, especially the division into thesis and hypothesis, follows from this premise. According to Murray, this point of view is the teaching of the Church and it is present even in the allocution of Pius XII Ci riesce, in which the Pope makes two

to the rational and moral nature of man; 2) they are themselves contrary to the common good of society, which is established by what is true and good; 3) they are themselves injurious to the rights of others, especially to their right to be protected from evil and error and not to prevent them from doing good; 4) error and evil are a scandal, an opportunity for moral wrongdoing and a denial of truth. 
assumptions: 1) error has no right to exist, 2) he repeats the doctrine of tolerance and not of religious freedom. This teaching, according to Murray, is, therefore, a continuation of the line of Leo XIII and Gregory XVI, and has its roots in the medieval order of the christianitas. It only differs in the better separation of secular and spiritual power, and forbids secular power to interfere in religious matters. Moreover, this doctrine recognizes that certain types of external coercion are incompatible with personal freedom of conscience. According to Murray, before his publications, Catholic doctrine had reached its final stage of development under Leo XIII. ${ }^{27}$

\subsection{The contribution of the Second Vatican Council}

The Council devoted a separate document in the form of the Declaration on Religious Freedom Dignitatis Humanae to the problem we are discussing. The original scheme entitled De Relationibus Inter Ecclesiam et Statum necnon de Tolerantia Religiosa, which was submitted to the Council's Central Preparatory Commission, was to form part of chapter nine of the De Ecclesia Constitution. The scheme presented the Catholic teaching in the form it acquired at the end of the pontificate of Pius XII. However, after the first session of the Council, the Fathers asked for a radical rebuilding of the whole project De Ecclesia. However, in the early summer of 1963, John XXIII ordered the development of a separate schema of the document, which would deal with religious freedom. This task was entrusted to the Secretariat for Christian Unity, headed by Cardinal Augustine Bea. In effect, on December 7, 1965, the Fathers signed the document Dignitatis humanae. Already in the first point, the Declaration indicates the key assumptions on which the current teaching of the Church is based. First, freedom comes from a better understanding of human dignity in our time. This "awareness" of modern societies demands that public authority also be limited in such a way that the freedom of persons and of

${ }^{27}$ Pacem in terris speaks of human dignity, from which arises the right to internal personal freedom of religion, which is also mentioned in earlier doctrine. In other respects, according to Murray, John XXIII leaves the teaching intact. (The Problem of Religious Freedom, 15) 
associations is not too much restricted. Given these circumstances, the Council seeks to clarify the question of religious freedom by referring to its own tradition (where new things are always compatible with the old). ${ }^{28}$ Then there is an important statement that the Council teaches that the only true religion subsists in the Catholic and Apostolic Church. And every man is obliged to seek the truth and, having found it, to accept and preserve it. But the truth imposes itself on the conscience in no other way than by the power of truth itself. Last, since religious freedom presupposes the inadmissibility of coercion in the state, the Council leaves intact the traditional Catholic doctrine of the moral duty of men and women towards the true religion and the one Church of Christ.

Lawrence E. Brandt ${ }^{29}$ distinguishes three levels in the teaching of the document: ethical, political and theological. With regard to ethical doctrine, Brandt notes that human dignity is the foundation on which the rationale for religious freedom in the Council's teaching is based. As Murray wrote: "The dignity of the human person is not a legal or political principle, but the foundation of all legal and political principles." ${ }^{30}$ In the Council's perspective, man is seen as an subject living in society and therefore having inalienable rights, both positive and negative. He is the image of God, the rational and morally free agent of his acts, destined both for a good life on earth and for a supernatural life in God, under the guidance of the authority and Divine as well as human rights, both of which are mediated in the person by conscience. Human freedom is based on three principles ${ }^{31}$ :

${ }^{28}$ See: Dignitatis humanae, No. 1, http://www.vatican.va/archive/hist_councils/ ii_vatican_council/documents/vat-ii_decl_19651207_dignitatis-humanae_en.html.

${ }^{29}$ See: L.E. Brandt, John Courtney Murray and Religius Liberty: An American Experience, Roma: Pontificia Universita Lateranense, 1983, 317nn.

${ }^{30}$ See: J.C. Murray, Declaration on Religious Freedom: Commentary, in American Participation in the Second Vatican Council, New York: Sheed and Ward, 1967, 671.

31 Por. J.C. Murray The Declaration on Religious Freedom: A moment in Its Legislative History, in J.C. Murray, Religious Liberty: An End and a Beginning, NY: Macmillan, 1966, 39. 
1. Personal autonomy, according to which man seeking the meaning of his own existence is subject only to the laws governing the order of truth. This truth is accepted only on the basis of lasting proofs, and adherence to it is personal and free and occurs in conjunction with other people.

2. Secondly, personal judgment and choice in the human moral life cannot be excluded or replaced in any way, because the moral value of an act only occurs when it is done intentionally and freely. The human subject cannot be replaced from outside, in the matter of moral action, by the action of others aiming at entering into the role of the inner dynamism of intelligence and freedom.

3. Lastly, man needs around himself a space of inviolability, which must be there for him to be able to take responsibility for his own existence. This environment of freedom becomes a precept especially when it comes to man's relationship with God, which is the direct relationship of two persons and can therefore be built only freely, in response to God's invitation. The human response is also personal, whether it is acceptance or rejection. It is that kind of responsibility which cannot be shared with others. Hence the conclusion that to encroach on this kind of relationship from outside would mean irreparable loss and injury to the human response to God's call. Such "violence" wants to replace what cannot be replaced, it means disregarding the person.

These three conditions of freedom are also the foundation of the legal order. The requirements of authority can only be derived from the requirements of the human person. However, the definition of the conditions of human freedom itself is not enough to speak of religious freedom in the state. Such freedom is, in fact, a right, and therefore a legal relationship that also assumes a certain obligation for the other party. In this case, it is the duty of the state to refrain from any compulsion. The Declaration states this in several places:

"Government therefore ought indeed to take account of the religious life of the citizenry and show it favour, since the function of government is to make provision for the common welfare. However, it would clearly transgress the limits set 
to its power, were it to presume to command or inhibit acts that are religious." ${ }^{32}$

"Government is also to help create conditions favourable to the fostering of religious life, in order that the people may be truly enabled to exercise their religious rights and to fulfil their religious duties, and also in order that society itself may profit by the moral qualities of justice and peace which have their origin in men's faithfulness to God and to His holy will." 33

"At the same time, the Christian faithful, in common with all other men, possess the civil right not to be hindered in leading their lives in accordance with their consciences. Therefore, a harmony exists between the freedom of the Church and the religious freedom which is to be recognized as the right of all men and communities and sanctioned by constitutional law." 34

These statements refer to the second plane in the teaching of Dignitatis humanae - the political one. The Declaration takes a slightly different viewpoint of religious freedom than previous Church documents. While until now, freedom has been spoken of in the context of the relationship between the state and the Church, presently essential is the problem of freedom of society in the state. In this matter, the Council adopted the principle developed in the liberal Western tradition of "as much freedom as possible and only as much limitation as necessary":

„For the rest, the usages of society are to be the usages of freedom in their full range: that is, the freedom of man is to be respected as far as possible and is not to be curtailed except when and insofar as necessary." 35

\footnotetext{
${ }^{32}$ Dignitatis humanae, No. 3.

33 Ibid., No. 6.

${ }^{34}$ Ibid., No. 13.

35 Ibid., No. 7.
} 
The legal assumption for religious freedom is the equality of all citizens before the law, which in turn is based on the conviction that God created all people equal. This equality before the law guarantees equal freedom for all:

"Finally, government is to see to it that equality of citizens before the law, which is itself an element of the common good, is never violated, whether openly or covertly, for religious reasons. Nor is there to be discrimination among citizens." 36

It follows from this assumption that the Church never demands any special rights for herself that would distinguish her from other denominations:

"If, in view of peculiar circumstances obtaining among peoples, special civil recognition is given to one religious community in the constitutional order of society, it is at the same time imperative that the right of all citizens and religious communities to religious freedom should be recognized and made effective in practice." 37

Commenting on this passage, Murray notes that the Council's intention is to point out that the establishment of Catholicism as a state religion is only a historical issue and not an object or consequence of Church doctrine. The intention of the Fathers was, according to Murray, to reject the possibility of establishing Catholicism as a state religion even as a purely historical law of development for a given society. ${ }^{38}$ In this sense, religious freedom, which is the subject of the Church's doctrinal teaching, becomes a thesis. Thus, both in theory and in practice, the division into theses and hypotheses disappears, and Catholic teaching is consistent in every case. Even when the Church demands freedom for herself, this

\footnotetext{
${ }^{36}$ Ibid., No. 6.

${ }^{37}$ Ibid., No. 6.

${ }^{38}$ See: J.C. Murray, The Issue of Church and State At Vatican Council II, in Theological Studies, 27 (December 1966), 595.
} 
is nothing more than the establishment of true freedom, not some form of privilege in the state:

"The freedom of the Church is the fundamental principle in
what concerns the relations between the Church and
governments and the whole civil order. [...] the Church
claims freedom for herself in her character as a spiritual
authority, established by Christ the Lord, upon which there
rests, by divine mandate, the duty of going out into the whole
world and preaching the Gospel to every creature.
The Church also claims freedom for herself in her character
as a society of men who have the right to live in society in
accordance with the precepts of the Christian faith." ${ }^{39}$

On the one hand, the freedom of the Church's institution is established, on the other hand, the institution of state intolerance is denied. The Church as a divine-human organism discovers her transcendent mission, to fulfil which she needs freedom in the social and state dimension. This mission, however, has no legal consequences, since it belongs to a different order.

The question of the nature of the Church and her freedom refers directly to the third dimension of teaching contained in the Declaration, namely, theological doctrine. The freedom of the Church has its origin in the transcendent order and is nothing else than participation in the freedom of the Son of God - the Head of the Church. The freedom of the Church is based on the revealed Word of God and the freedom of the human person on the rational truth of human dignity. Therefore, the former belongs to the order of Revelation, the latter to the truths of the rational order. The Council, however, did not introduce such a clear separation in the justification of human and ecclesiastical freedom. In the number 9 of the Declaration, the Council says that the doctrine of human freedom, although not explicitly expressed, is rooted in God's Revelation and should therefore be carefully observed by Christians. In support of this thesis, the Council refers to the constantly proclaimed teaching of the Fathers of the Church, which is rooted in the example of the

${ }^{39}$ Dignitatis humanae, No. 13. 
life and teaching of Christ himself, who never forced anyone to accept the faith:

„God calls men to serve Him in spirit and in truth, hence they are bound in conscience but they stand under no compulsion. God has regard for the dignity of the human person whom He Himself created and man is to be guided by his own judgment and he is to enjoy freedom. This truth appears at its height in Christ Jesus, in whom God manifested Himself and His ways with men." 40

The Council recalls the promises that Jesus Christ linked to the acceptance of faith in His proclamation of the kingdom of God, as well as the punishments that those who reject this teaching will face. However, the possible punishment was postponed by the Lord to the day of judgment, and in the present condition, the Church is to be guided by the principles of the parable of the wheat and the tares. Furthermore, the Lord Jesus himself rejected the political interpretation of his mission in order to serve His brothers and to give His life for the salvation of the world. He is a gentle Lord, a servant who will not break the fractured reed nor extinguish the smouldering wick. His example was also followed by the Apostles, courageously defending God's laws, listening more to God than to people, but never using violence against the rightful authority or against people. From this comes the conclusion that "the Church is following the way of Christ and the apostles when she recognizes and gives support to the principle of religious freedom as befitting the dignity of man and as being in accord with divine revelation." 41

As a consequence, Christians are called to shape their conscience to listen to the holy and certain teaching of the Church and to witness to faith, even up to shedding their own blood. This duty to proclaim Christ given to His every disciple is, however, accompanied by a prohibition to use means that are contrary to the evangelical spirit:

"The disciple is bound by a grave obligation toward Christ, his Master, ever more fully to understand the truth received

\footnotetext{
${ }^{40}$ Ibid., No. 11.

${ }^{41}$ Ibid., No. 12.
} 
from Him, faithfully to proclaim it, and vigorously to defend it, never-be it understood-having recourse to means that are incompatible with the spirit of the Gospel." 42

Summarizing the Council's teaching on religious freedom, it should be noted first of all that the Church, through this Declaration, turns out to be the only religious institution in the world that develops the issue of freedom for all people, not just her own followers. Moreover, Catholicism proves to be the only religion aware of the necessity of self-restraint in certain circumstances in the name of the common good. Finally, by discovering the fundamental level of human freedom anchored in the dignity of man as a person, the Church becomes a defender of the freedom of all people, not only her own followers. After Dignitatis humanae, religious freedom entered into the positive teaching of the Church and thus became one of the manifestations of the sacred Tradition found in the sources of Revelation and in the Fathers. In this sense, freedom, therefore, is also the object of the Church's defence against the temptations to rule over human consciences, be it by state systems or other religions. With regard to religious freedom, the Catholic Church has developed a teaching that is capable of reconciling, on the one hand, the democratic and pluralistic nature of modern societies and, on the other, the unchanging demands of truth. It is, therefore, a doctrine which renders unto God what is God's and unto Caesar what is Caesar's, a doctrine according to which there is no contradiction between a just order of authority and religion. Finally, the Council's teaching reveals in man another dimension of his likeness to the Creator, which is the vocation to communion with God, which only makes sense in freedom.

\section{The "Hermeneutics of Continuity" as an Answer to the Question of the Credibility of the Church's Teaching}

According to Böckenförde, where evolution leads from negation to affirmation, one can no longer speak of evolution, but of a break with tradition. Such a thesis in relation to the teaching of freedom 
would lead to further difficult questions about the credibility of the Church's modern teaching on this issue. If, in fact, there is a rupture, what kind or degree of certainty does the Church's current teaching in this matter have? Can it be said that the Church has indeed opted for the kind of understanding of freedom that she presents today, or was it merely the result of adaptation to changing times, an element of policy aimed at modernising her teaching? What is the guarantee of the authenticity of this teaching today?

Böckenförde in his further analyses reaches a distinction between the legal order in the State and the moral order that applies to each individual on the basis of his or her conscience. According to the German philosopher, the pre-conciliar teaching was mistaken in its postulate that religious truth about the exclusivity of the Catholic faith should be transferred to the legal state system. This would inevitably lead to conflict in the state, and yet the task of the law is primarily to regulate human relations peacefully and fairly. The Council's declaration, without giving up its claims to the truths of the faith, nevertheless abandoned the political and legal implications and thus confirmed religious freedom on the one hand and the real requirements of the faith on the other. In this light, the question of a change in teaching looks completely different, as it turns out that the Church has not given up her teaching, but rather certain practical implications. This would at least be the conclusion of the Böckenförde text. However, the questions raised above remain open. The problem calls for further clarification, not least because the Church is constantly being accused of condemning freedom and of upholding the principles of absolutism in various manifestations of religious, political and moral life. ${ }^{43}$ Thus, in the face of the evolution that has taken place, there is a question about the meaning, rank and credibility of Catholic teaching on human freedom.

${ }^{43}$ See for example the book: T. Bartoś, K. Bielawski, Ścieżki wolności, Kraków: Homini, 2007, 100nn. 
Pope Benedict XVI rejected the hermeneutic of rupture, which I presented on the example of the German philosopher's text. ${ }^{44}$ Undoubtedly, in order to see the continuity in the teaching of the Magisterium on the question of freedom, it is necessary to look at the question in a multifaceted way, taking into account both the content of the documents, the context in which they appeared, who they were addressed to, their rank and a number of other circumstances. ${ }^{45}$ The methodology for studying such issues is presented in the document of the International Theological Commission "Memory and Reconciliation. The Church and the Faults of the Past." ${ }^{\text {" }}$ For us, the most important is chapter four, which discusses the method of

\footnotetext{
${ }^{44}$ On the fortieth anniversary of the conclusion of the Council, Benedict XVI gave a speech in which he analyzed the reception of the Council over the past decades. According to the Pope, there were two hermeneutics, that is, two ways of interpreting the Council's transformation: "On the one hand, there is an interpretation that I would call 'a hermeneutic of discontinuity and rupture;' it has frequently availed itself of the sympathies of the mass media, and also one trend of modern theology. On the other, there is the 'hermeneutic of reform,' of renewal in the continuity of the one subject-Church which the Lord has given to us. She is a subject which increases in time and develops, yet always remaining the same, the one subject of the journeying People of God." Benedict XVI in his address to the Roman Curia on the correct interpretation of the Second Vatican Council. Source: http://www.vatican.va/content/benedict-xvi/en/speeches/2005/december/documen ts/hf_ben_xvi_spe_20051222_roman-curia.html.

${ }^{45}$ It is worth noting that the documents of the Magisterium on freedom remain in connection with their predecessors. Thus, for example, Leo XIII, in his encyclical Immortale Dei, referred to Gregory XVI and Pius IX, entirely confirming their teaching and then extracting from it a positive content. Similarly, the Second Vatican Council proclaims the "hermeneutics of continuity" about itself, that is, it speaks of the confirmation and deepening of the teaching to date.: "This Vatican Council [...] searches into the sacred tradition and doctrine of the Church-the treasury out of which the Church continually brings forth new things that are in harmony with the things that are old." "Religious freedom, in turn, which men demand as necessary to fulfil their duty to worship God, has to do with immunity from coercion in civil society. [...] the council intends to develop the doctrine of recent popes on the inviolable rights of the human person and the constitutional order of society." Dignitatis humanae, No. 1.

${ }^{46}$ Memory and Reconciliation. The Church and the Faults of the Past [Pamięc $i$ pojednanie. Kościół $i$ winy przeszłości], transl. Janusz Królikowski, Sandomierz, 2000. The document was to prepare, from the theological and methodological point of view, the confession of the Church's faults, made by John Paul II on March 12, 2000.
} 
studying the phenomena of the past and how to evaluate them in our times. The document lists three principles that should be taken into account in the theological evaluation of events. ${ }^{47}$ For us, the third principle, the principle of paradigm shift, will be most important:

"While before the Enlightenment there existed a sort of
osmosis between Church and State, between faith and
culture, morality and law, from the eighteenth century
onward this relationship was modified significantly. The
result was a transition from a sacral society to a pluralist
society, or, as occurred in a few cases, to a secular society.
The models of thought and action, the so-called 'paradigms'
of actions and evaluation, change. Such a transition has
a direct impact on moral judgments, although this influence
does not justify in any way a relativistic idea of moral
principles or of the nature of morality itself." 48

The principle of "paradigm shift" is crucial to the Church's teaching on freedom. While until the eighteenth century we can speak of this uniformity of Christian culture (although its erosion is already visible since the Reformation), in post-revolutionary times, as the document says, societies become pluralistic or secular. This means that different patterns of social behaviour are already in force, freedom is increasingly understood as the possibility to choose between diverse and contradictory philosophies, ways of life, religions, etc. In Christian society, the range of such "possible choices" was narrower, the level of certainty about certain truths of a worldview was higher and these truths were widely accepted. Private and social freedom, therefore, was directed by culture itself towards certain choices that were otherwise better suited to man's vocation in the light of divine revelation. It was therefore the Church who initially did not know how, in the new situation, to reconcile the two fundamental requirements of social life: the right to freedom and the duty of faithfulness to the truth. However, over the past two centuries, she has succeeded in developing certain universal

\footnotetext{
47 The first principle is the "principle of conscience," the second is the "principle of historicity."

${ }^{48}$ Memory and Reconciliation [Polish edition], op. cit., 5.1. [p.31].
} 
solutions that correspond to the requirements of coexistence of different religions in one society. We can talk here about the development of doctrine, but not about changing its principles.

Ernst Böckenförde is right when he writes that it is difficult to speak of development when its final result is "as A to non-A." Is this the case with the Church's statements on freedom?

The presented analysis of the papal documents reveals a rather gradual, though consistent, transition from a denial of freedom understood as arbitrariness to its affirmation, when it is understood as a genuinely human property inherent in human nature. This growth is in accordance with the criteria for the authentic development of Christian doctrine, first given by Vincent of Lerins, ${ }^{49}$ then by J.H. Newman ${ }^{50}$ and Y. Congar. ${ }^{51}$ Here I have only considered the question of religious freedom (and secondarily freedom of conscience). The gradual and authentic development of the doctrine can also be seen in relation to freedom in general, as a property of human nature, and also in relation to political freedom. In each of these aspects, the same clearly oriented evolution of the Church's position can be seen.

Finally, one more important observation should be made. The perspective in which the Böckenförde presents the development of the Magisterium assumes a contradiction in the statements and not in their subject matter. In order to understand this, reference should be made to the distinction between the textual (verbal) layer and the semantic layer of a document. Every time the term "freedom" appears in the texts of ecclesiastical documents, it is necessary to

${ }^{49}$ St. Vincent of Lerins, Commonitorium [Pismo napominajace], chap. 23, quote after: Liturgia Godzin, vol. 4, Pallotinum, 1988, 283.

${ }^{50}$ Essay on the Development of Christian Doctrine (1845) [O rozwoju doktryny chrześcijańskiej], Polish transl.: J.W. Zielińska, Warszawa: PAX, 1957.

${ }^{51}$ According to Congar, there are five factors that must occur simultaneously in order to speak of true reform in the Church. These are: 1) the primacy of charity 2) the primacy of the pastoral factor 3) the communion with the whole 4) patience 5) the return to tradition, which means that everything that appears new in the Church must have somehow existed in it previously. See: Yves Congar, Prawdziwa i fatszywa reforma $w$ Kościele, transl. A. Ziernicki, Kraków: Znak, 2001. 
determine the reality of the word as intended by the writer. Over the past two centuries, it is not so much the Church's teaching on freedom that has changed, but the concept of freedom that has been used in ecclesiastical documents. The word "freedom" simply meant something else in the letters of Pius VI and something else in the encyclicals of John XXIII and the documents of the Second Vatican Council. It is a fact that there can be no development when the end result is a denial of the starting point. However, this applies only to the conceptual (semantic) layer and not to the textual (verbal) layer. In this case, however, the contradiction does not exist in the semantic layer, but in the verbal layer, which results from the change in the concept of freedom. Where the old documents condemned freedom, they spoke of freedom understood as arbitrariness, disorder, anarchy, licentiousness, etc. When the Second Vatican Council speaks of freedom, it means freedom either as a natural property of man or his vocation to communion with God, or as a free choice, which is an aspect of free will. Nevertheless, in each of these meanings, freedom is a natural good and demands only appropriate realization. On the other hand, when freedom means disorder and arbitrariness, it is in fact a denial of that freedom and a corruption of some good and order. These two "freedoms" are related to each other "as A to non-A."

\section{Bibliography}

Bartoś, T., Bielawski, K., Ścieżki wolności, Kraków: Homini, 2007.

Benedict XVI, Address of His Holiness Benedict XVI to the Roman Curia Offering Them His Christmas Greetings, http://w2.vatican.va/content/ benedict-xvi/en/speeches/2005/december/documents/hf_ben_xvi_spe _20051222_roman-curia.html (access 14.11.2015).

Böckenförde, E.-W., Wolność - Państwo - Kościót, transl. P. Kaczorowski, Kraków: Znak, 1994.

Brandt, L.E., John Courtney Murray and Religius Liberty: An American Experience, Roma: Pontificia Universita Lateranense, 1983.

Collectio Bullarum, Brevium, Allocutionum, Epistolarumque PP. Pii VI contra constitutionem civilem cleri Gallicani ejusque authores et fautores, etc. Londini: Ex officina Cox et Baylis, Great Queen Street, Lincoln's-Inn-Fields, 1821. 
Congar, Y., Prawdziwa i fałszywa reforma w Kościele, transl. A. Ziernicki, Kraków: Znak, 2001.

Hittinger, F.R., Pascendi Dominici Grgis at 100, Nova et Vetera English Edition, vol. 4, (2006) No. 4, 843-80.

International Theological Commission, Memory and Reconciliation. The Church and the Faults of the Past. [Pamięć i pojednanie. Kościót $i$ winy przeszłości], transl. Janusz Królikowski, Sandomierz, 2000.

John XXIII, Pacem in terris, in Dokumenty nauki społecznej Kościoła, Pt. 1, ed. M. Radwan, Rzym-Lublin, 1996, 361-401

Leo XIII, Immortale Dei, http://www.vatican.va/content/leo-xiii/en/ency clicals/documents/hf_l-xiii_enc_01111885_immortale-dei.html.

Leo XIII, Libertas, http://www.vatican.va/content/leo-xiii/en/encyclicals/ documents/hf_l-xiii_enc_20061888_libertas.html.

Murray, J.C., Declaration on Religious Freedom: Commentary, in American Participation in the Second Vatican Council, New York: Sheed and Ward, 1967.

Murray, J.C., The Issue of Church and State at Vatican Council II, Theological Studies, 27 (December 1966), 580-606.

Murray, J.C., The Problem of Religious Freedom, London-Dublin: Geoffrey Chapman, 1965.

Murray, J.C., Religious Liberty: An End and a Beginning, NY: Macmillan, 1966.

Newmann, J.H., Essay on the Development of Christian Doctrine (1845) [O rozwoju doktryny chrześcijańskiej], Polish transl.: J.W. Zielińska, Warszawa: PAX, 1957.

Papciak, K.F., "Stolica Apostolska a ONZ wobec praw człowieka w relacjach międzynarodowych," Saeculum Christianum 6 (1999), No. 1, 189-99.

Pius IX, Quanta cura, in Encyclical Letter Quanta Cura \& the Syllabus of Errors: of the Supreme Pontiff Pius IX: Condemning Current Errors: December 8, 1846. Kansas City (MO) 1998.

Pius IX, Syllabus errorum, in Quanta Cura in: Encyclical Letter Quanta Cura \& the Syllabus of Errors: of the Supreme Pontiff Pius IX: Condemning Current Errors: December 8, 1846. Kansas City (MO) 1998.

Pius XI, Mit brennender Sorge, http://www.vatican.va/content/pius-xi/en/ encyclicals/documents/hf_p-xi_enc_14031937_mit-brennender-sorge .html.

Pius XII, Ci riesce, Warszawa: Te Deum, 2004.

Sesboüe, B., Władza w Kościele. Autorytet, prawda $i$ wolność, transl. P. Rak, Kraków: Wyd. M, 2003. 
Vincent of Lerins [Wincenty $\mathrm{z}$ Lerynu], Commonitorium [Pismo napominajace], chap. 23, Liturgia Godzin, vol. 4, Pallotinum, 1988. 